\title{
Low-protein diet in adult male rats has long-term effects on metabolism
}

\author{
Ananda Malta, Júlio Cezar de Oliveira, Tatiane Aparecida da Silva Ribeiro, \\ Laize Peron Tófolo, Luiz Felipe Barella, Kelly Valério Prates, \\ Rosiane Aparecida Miranda, Ghada Elmhiri', Claudinéia Conationi da Silva Franco, \\ Aryane Rodrigues Agostinho, Amanda Bianchi Trombini, Audrei Pavanello, \\ Clarice Gravena, Latifa Abdennebi-Najar ${ }^{1}$ and Paulo Cezar de Freitas Mathias
}

Laboratory of Secretion Cell Biology, Department of Cell Biology and Genetics, Block H67, Room 19, State University of Maringá, Colombo Avenue 5970, 87020-900 Maringá, Parana, Brazil

${ }^{1}$ UPSP-EGEAL Institut Polytechnique LaSalle de Beauvais, Beauvais Cedex, France

\begin{abstract}
Nutritional insults during developmental plasticity have been linked with metabolic diseases such as diabetes in adulthood. We aimed to investigate whether a low-protein (LP) diet at the beginning of adulthood is able to program metabolic disruptions in rats. While control rats ate a normal-protein (23\%; NP group) diet, treated rats were fed a LP (4\%; LP group) diet from 60 to 90 days of age, after which an NP diet was supplied until they were 150 days old. Plasma levels of glucose and insulin, autonomous nervous system (ANS), and pancreatic islet function were then evaluated. Compared with the NP group, LP rats exhibited unchanged body weight and reduced food intake throughout the period of protein restriction; however, after the switch to the NP diet, hyperphagia of $10 \%(P<0.05)$, and catch-up growth of $113 \%(P<0.0001)$ were found. The LP rats showed hyperglycemia, insulin resistance, and higher fat accretion than the NP rats. While the sympathetic tonus from LP rats reduced by $28 \%$, the vagus tonus increased by $21 \%(P<0.05)$. Compared with the islets from NP rats, the glucose insulinotropic effect as well as cholinergic and adrenergic actions was unaltered in the islets from LP rats. Protein restriction at the beginning of adulthood induced unbalanced ANS activity and fat tissue accretion later in life, even without functional disturbances in the pancreatic islets.
\end{abstract}

Correspondence should be addressed to P C F Mathias Email pmathias@uem.br

\section{Key Words}

- adulthood

- protein restriction

- autonomous nervous system

- pancreatic islets

\section{Introduction}

The developmental origins of health and disease (DOHaD) concept originates from the epidemiological, clinical, and experimental evidence that insults during early life can program metabolic dysfunctions later in life and cause great impacts on world health and links the action of poor nutrition at critical development stages with the onset of metabolic diseases later in life. Many metabolic diseases with high worldwide prevalence such as obesity, type 2 diabetes, and hypertension can have their etiology during fetal development (Barker 2004).
One very potent insult is malnourishment, including protein restriction, during pregnancy, which causes intrauterine growth restriction leading to newborns with low body weight (BW) and/or small size. These neonates are at high risk for developing metabolic diseases later in life (Greenwood \& Bell 2003). In addition, protein restriction during gestation and lactation has been observed in both humans and experimental animals to cause obesity during adulthood (Barker \& Bagby 2005, Cripps \& Ozanne 2006). 
During fetal development, nutrients, including amino acids, are crucial to brain maturation, which allows neurons to connect to each other and build the neuronal network, enabling the brain to control body functions such as metabolism. Hypothalamic immaturity caused by protein malnourishment during fetal development has been observed in both children and rodents, and these findings were associated with disruptions of metabolic homeostasis in adulthood, demonstrating the important role of the hypothalamus in the regulation of energy metabolism (Plagemann et al. 2000a, Bouret et al. 2008). Protein restriction during lactation induces metabolic reprograming in adult rats (de Oliveira et al. 2012a). Indeed, it has been shown in rodents that the milksuckling phase is pivotal for producing neuronal network connections (Lesage et al. 2006). Recently, our laboratory has shown that protein malnourishment during adolescence can also cause metabolic dysfunctions during adulthood (de Oliveira et al. 2012b), leading us to conclude that the peripubertal phase could be another window for metabolic programing beyond perinatal development. It is important to note that metabolic programing can also be setup even before conception. Indeed, adult male rats that were fed a high-fat diet were able to transmit their impaired glucose/insulin homeostasis phenotype to their female offspring (Ng et al. 2010). Disruption of glycemic homeostasis and pancreatic $\beta$-cell dysfunction, among other metabolic alterations, are often observed later in life as a consequence of metabolic programing ( $\mathrm{Ng}$ et al. 2010).

It has been reported that the acute effects of food as well as protein deprivation in adulthood were able to induce changes in glucose-insulin homeostasis and energy metabolism due to imbalances in the autonomous nervous system (ANS; Leon-Quinto et al. 1998). In addition, hypothalamus malfunctions and behavioral abnormalities induced by protein restriction during adulthood have been observed (Alamy \& Bengelloun 2012); however, these effects were observed immediately after the diet-restriction treatment and not after diet recovery. Beyond the hypothalamus, it is striking that pancreatic $\beta$-cell are one among several other targets of early injuries, which can manifest as dysfunction in adulthood (Barbosa et al. 2002, Reusens \& Remacle 2006). Taken together, these studies indicate that metabolic programing is not merely an adaptation and can influence lifelong health. However, it has not been determined whether protein restriction during early adulthood can affect metabolism later in life. To address this question, our current study tests whether protein malnourishment during early adulthood can provoke changes in metabolism, including pancreatic islet dysfunction, later in adulthood.

\section{Materials and methods}

\section{Animals and protein malnourishment}

Male 60-day-old Wistar rats from 12 different litters were randomly chosen for the study and distributed into two groups (6 litters/group). One group of rats was supplied with a normal-protein (NP; $23 \% \mathrm{w} / \mathrm{w}$ protein) diet and allowed to feed ad libitum (Nuvital, Curitiba, PR, Brazil) throughout the experimental period (the NP group), while the other group of rats (the low-protein (LP) group) received a $\mathrm{LP}(4 \% \mathrm{w} / \mathrm{w}$ protein) diet containing the same amount of calories as the normal diet from 60 to 90 days of age, as described previously (de Oliveira et al. 2011). After 90 days of age, the LP group received a NP diet for another 60 days to allow dietary recovery. Because sex differences between insulin levels and glucose tolerance have been observed in some early poor-protein feeding studies (Lopes Da Costa et al. 2004), only male rats were used in the experiments. Throughout the experimental period, the rats (five rats per cage) were kept under controlled conditions, including temperature $\left(22 \pm 2^{\circ} \mathrm{C}\right)$ and photoperiod (0700-1900 h), and allowed to eat and drink ad libitum.

The rats were supplied by the Central Animal Facility of the State University of Maringa. The Ethical Committee for Animal Experiments of the State University of Maringá, which adheres to Brazilian Federal Law, approved this protocol.

\section{BW and food intake}

BW and chow consumption were recorded every 2 days during the poor diet treatment from 60 to 90 days of age. Data collection was continued until the end of the experimental protocol when rats were 150 days old, at which point all animals were used for biochemistry and physiological analysis. Food intake (FI) values were calculated as the difference between the amount of food remaining (final diet (Df)) and the total food available (initial diet $(\mathrm{D} i)$ ), divided by the number of days and the number of rats in the cages: $(\mathrm{FI}(\mathrm{g})=(\mathrm{D} f-\mathrm{D} i) / 2 / 5)$. The BW gain was also calculated by subtracting the daily $\mathrm{BW}$ value throughout the experimental period by the starting BW value at 60 days old (beginning of the diet treatment) of all the rats in both experimental groups. The area under the curve (AUC) of the entire observation period (60-150 days) for BW gain and food intake was also calculated.

Published by Bioscientifica Ltd. 


\section{Intravenous glucose tolerance test}

When the rats were 150 days old, animals in both groups underwent a surgical procedure under ketamine and xylazine anesthesia (3 and $0.6 \mathrm{mg} / 100 \mathrm{~g}$ of BW respectively) to implant a silicone cannula into the right jugular vein that attached in the dorsal region of the neck. The cannula was treated with heparinized saline solution ( $50 \mathrm{IU}$ heparin $/ \mathrm{ml} ; 0.9 \% \mathrm{w} / \mathrm{v}$ of saline solution) before implantation to avoid blood clots. After a $12 \mathrm{~h}$ fast (1900-0700 h) and without anesthesia, a glucose load $(1 \mathrm{~g} / \mathrm{kg} \mathrm{BW})$ was infused through the cannula. Blood samples were collected immediately before glucose infusion ( 0 min) and at 5, 15, 30, and 45 min after infusion.

The blood samples collected previously ( $0 \mathrm{~min})$ to the intravenous glucose tolerance test (ivGTT) were used to assess the fasting levels of glucose and insulin. Plasma obtained from the other blood samples was stored at $20^{\circ} \mathrm{C}$ for subsequent determination of the glucose concentration by the glucose oxidase method (Trinder 1969), with a commercial kit (Gold Analisa, Belo Horizonte, MG, Brazil). Insulin level was determined by RIA (Scott et al. 1981), with a gamma counter (Wizard ${ }^{2}$ Automatic Gamma Counter-2470, PerkinElmer, Shelton, CT, USA), using human insulin as the standard, an anti-rat insulin antibody (Sigma-Aldrich), and ${ }^{125}$ I-labeled recombinant human insulin (PerkinElmer). The insulin intra- and interassay coefficients of variation were respectively 12.2 and 9.8 , and the limit of detection was $0.006 \mathrm{ng} / \mathrm{ml}$.

\section{Insulin sensitivity index}

Because the insulin sensitivity index (ISI) used by Matsuda \& DeFronzo (1999) gives a reasonable approximation of the whole-body insulin sensitivity, we used this index, with small modifications, to measure the body insulin sensitivity in our experimental model. To calculate ISI, we used the following calculation: $I S I=10^{4}$ / $\sqrt{ }\left((\right.$ fasting glycemia $\times$ fasting insulinemia $) \times\left(\right.$ AUC $\Delta_{\text {glycemia }} \times$ AUC $\left.\left.\Delta_{\text {insulinemia }}\right)\right)$. The glycemia $\left(\Delta_{\text {glycemia }}\right)$ and insulinemia increment $\left(\Delta_{\text {insulinemia }}\right)$ of each time from ivGTT was obtained by subtracting the fasting plasma glucose and insulin levels. Increases in the total $\Delta_{\text {glycemia }}$ and $\Delta_{\text {insulinemia }}$ were calculated by using the glycemia and/or insulinemia AUC at 45 min post ivGTT.

\section{Electrical recording of nerves}

When the rats were 150 days old, a batch of rats from each group was anesthetized with thiopental (45 mg/kg BW) after a $12 \mathrm{~h}$ fast and a surgical longitudinal incision was made on the anterior cervical region. Under a dissecting microscope, the nerve bundle of the left vagus superior branch was severed from the carotid artery, close to the trachea. The nerve trunk was pulled with a fine cotton line, and a pair of recording silver electrodes $(0.6 \mathrm{~mm}$ diameter) was placed under the nerve. The nerve was covered with silicone oil to avoid further dehydration. The electrode was then connected to an electronic device (Bio-Amplificator, Insight, Ribeirão Preto, SP, Brazil) that amplified the electrical signal up to 10000 times. To exclude low and high frequencies, recordings of $<1$ and $>80 \mathrm{kHz}$ were discarded by a filter. The neural signal output was acquired by an Insight interface (Insight), viewed online and stored on a personal computer running software developed by Insight. During all data acquisition, animals remained in a Faraday cage to avoid any electromagnetic noise. Nerve activity was analyzed by the number of spikes over the course of $5 \mathrm{~s}$. Spikes were characterized by depolarization that surpassed $0 \mathrm{mV}$. After stabilization of the signal over the course of $2 \mathrm{~min}$, 20 record frames of $15 \mathrm{~s}$ were randomly chosen from each animal for spike counting. The average numbers of spikes were used to calculate the rate of nerve firing for each rat.

The sympathetic branch nerve from the superior cervical ganglia was dissected from another batch of anesthetized rats from both experimental groups, also after $12 \mathrm{~h}$ of fasting. The electrode was placed under the sympathetic branch nerve. Firing rates were obtained as described for the vagus nerve.

\section{Pancreatic islets isolation}

Pancreatic islets were isolated by the collagenase technique as previously described (Gravena et al. 2002). At 150 days of age, rats were anesthetized with thiopental (45 mg/kg BW) and immediately decapitated, and the abdominal wall was cut and open. After that, $8 \mathrm{ml}$ Hanks buffered saline solution (HBSS (mmol/l): NaCl, 136.9; $\mathrm{KCl}$, 5.4; $\mathrm{MgSO}_{4} 7 \mathrm{H}_{2} \mathrm{O}, 0.81 ; \mathrm{Na}_{2} \mathrm{HPO}_{4}, 0.34 ; \mathrm{KH}_{2} \mathrm{PO}_{4}, 0.44$; $\mathrm{CaCl}_{2} 2 \mathrm{H}_{2} \mathrm{O}, 1.26 ; \mathrm{NaHCO}_{3}, 4.16$; glucose, 0.06; BSA 15, and $\left(\mathrm{v} / \mathrm{v} ; \mathrm{O}_{2}, 95 \%+\mathrm{CO}_{2}, 5 \%\right.$ mixed)/10 min, $\mathrm{pH} 7.4$ ) containing $(\mathrm{w} / \mathrm{v}) 0.1 \%$ collagenase type XI, 5\% BSA, and $0.6 \%$ HEPES ( $N$-(2-hydroxyethyl-piperazine)- $N^{\prime}$-(2-ethanesulphonic acid)) (Sigma-Aldrich) were injected into each rats' common bile duct.

The pancreas, swollen with the collagenase solution, was quickly excised and incubated in a glass beaker for 17-18 $\mathrm{min}$ at $37^{\circ} \mathrm{C}$. The suspension was then discarded, and the precipitate was washed three times with HBSS.

Published by Bioscientifica Ltd 
Islets were easy to find in the final precipitate and were collected with the aid of a stereomicroscope. At least three rats from three different litters were used for each experimental procedure from each group.

\section{Stimulation of insulin secretion}

To adapt isolated islets to a baseline glucose concentration $(5.6 \mathrm{mmol} / \mathrm{l})$, the islets were pre-incubated for $60 \mathrm{~min}$ in $1 \mathrm{ml}$ of Krebs-Ringer solution $((\mathrm{mmol} / \mathrm{l}): \mathrm{NaCl}, 115$; $\mathrm{NaHCO}_{3}, 24 ; \mathrm{KCl}, 1.6 ; \mathrm{MgCl}_{6} \mathrm{H}_{2} \mathrm{O}, 1 ; \mathrm{CaCl}_{2} 2 \mathrm{H}_{2} \mathrm{O}, 1 ; \mathrm{BSA}$, $15)$ at $\mathrm{pH} 7.4$ containing $5.6 \mathrm{mmol} / \mathrm{l}$ glucose. This solution was gassed with (v/v) $95 \% \mathrm{O}_{2}$ and $5 \% \mathrm{CO}_{2}$ (mixture) to maintain $\mathrm{pH}$ 7.4.

After the pre-incubation, islets were incubated with different glucose concentrations for another $60 \mathrm{~min}$. The supernatants from the incubations were collected and stored for further insulin measurements. To study muscarinic acetylcholine receptor (mAChR) function, some islets from other batches were incubated after preincubation for a further $60 \mathrm{~min}$ in Krebs-Ringer solution containing $8.3 \mathrm{mmol} / \mathrm{l}$ glucose and/or $8.3 \mathrm{mmol} / \mathrm{l}$ glucose $+10 \mu \mathrm{mol} / 1$ acetylcholine in the presence of $10 \mu \mathrm{mol} / \mathrm{l}$ neostigmine to avoid the acetylcholinesterase action found in the islets. In addition, a non-selective $\mathrm{mAChR}$ antagonist, atropine $(10 \mu \mathrm{mol} / \mathrm{l})$, was also used. To block the function of the mAChR subtypes $\mathrm{M}_{2}$ and $\mathrm{M}_{3}$ the following antagonists were used: $1 \mu \mathrm{mol} / 1$ methoctramine and $100 \mu \mathrm{mol} / \mathrm{l}$ 4-diphenylacetoxy- $N$-methylpiperidine methiodide, also known as 4-DAMP.

Doses of the antagonists had been tested previously, and the concentrations that induced at least $20 \%$ inhibition or potentiation of the insulinotropic effect of $10 \mu \mathrm{mol} / 1$ acetylcholine in islets incubated with $8.3 \mathrm{mmol} / \mathrm{l}$ glucose were chosen.

To study the function of adrenoceptors in another batch of islets from both groups, islets, after preincubation with $5.6 \mathrm{mmol} / \mathrm{l}$ glucose, were stimulated with a high glucose concentration $(16.7 \mathrm{mmol} / \mathrm{l})$ either in the presence of $1 \mu \mathrm{mol} / 1$ epinephrine and an $\alpha_{2}$ adrenoceptor antagonist, yohimbine, at $10 \mu \mathrm{mol} / 1$ or in the presence of epinephrine and a $\beta_{2}$-adrenoceptor antagonist, propranolol, at $1 \mu \mathrm{mol} / \mathrm{l}$.

As with the muscarinic receptor studies, doses of antagonists had been tested previously, and concentrations that induced at least $50 \%$ inhibition or potentiation of insulin secretion stimulated with $16.7 \mathrm{mmol} / \mathrm{l}$ glucose were chosen. All drugs used to study the muscarinic and adrenergic function were purchased from Sigma-Aldrich.

\section{Fat pad weight evaluation}

At 150 days old, the rats were anesthetized with thiopental (45 mg/kg BW) and killed by decapitation. Fat pad stores (retroperitoneal, periepididymal, and visceral) were removed and weighed to assess the state of obesity.

\section{Statistical analyses}

Results are given as the mean \pm s.E.M., and were subjected to Student's $t$-test or one-way ANOVA followed by Bonferroni's post-test analysis. $P<0.05$ was considered statistically significant. Tests were carried out using GraphPad Prism, version 5.0 for Windows (GraphPad Software, Inc., San Diego, CA, USA).

\section{Results}

Effects of a LP diet treatment during adulthood on BW gain, food intake, fat pad store, and plasma levels of glucose and insulin

As shown in Table 1, the LP diet given over 30 days did not change the final BW or body length of the rats when they reached 150 days old. While a modest increase of $8 \%$ in the fasting glycemia was observed in the LP rats compared with the NP rats $(P<0.05, n=15-16)$, the fasting insulinemia did not present any significant difference between the two groups. Tissue weight of the fat pads showed that treatment with the LP diet induced a higher increase in the retroperitoneal (29\%; $P<0.0001, n=20-25)$,

Table 1 Effects of LP diet treatment started at the beginning of adulthood on adult rats later in life. Data are presented as mean \pm S.E.M. obtained from 6-25 rats of each experimental group

\begin{tabular}{|c|c|c|}
\hline $\begin{array}{l}\text { Biometric } \\
\text { parameters }\end{array}$ & NP & LP \\
\hline Body weight (g) & $460.9 \pm 6.31$ & $448.2 \pm 7$ (NS) \\
\hline Body length $(\mathrm{cm})$ & $24.22 \pm 0.12$ & $23.85 \pm 0.2$ (NS) \\
\hline $\begin{array}{l}\text { Retroperitoneal } \\
\text { fat }(g / 100 \mathrm{~g} \mathrm{BW})\end{array}$ & $1.63 \pm 0.07$ & $2.11 \pm 0.08^{*}$ \\
\hline $\begin{array}{l}\text { Periepididymal } \\
\text { fat }(\mathrm{g} / 100 \mathrm{~g} \mathrm{BW})\end{array}$ & $1.57 \pm 0.08$ & $1.80 \pm 0.04^{\dagger}$ \\
\hline $\begin{array}{l}\text { Visceral fat } \\
\quad(\mathrm{g} / 100 \mathrm{~g} \mathrm{BW})\end{array}$ & $0.95 \pm 0.04$ & $1.07 \pm 0.04^{\dagger}$ \\
\hline $\begin{array}{l}\text { Fasting glycemia } \\
(\mathrm{mmol} / \mathrm{l})\end{array}$ & $5.31 \pm 0.09$ & $5.73 \pm 0.13^{\dagger}$ \\
\hline $\begin{array}{l}\text { Fasting insulin } \\
(\mathrm{pmol} / \mathrm{l})\end{array}$ & $40.48 \pm 3.64$ & $44.33 \pm 3.24$ (NS) \\
\hline ISI & $130.0 \pm 9.57$ & $99.42 \pm 8.36^{\dagger}$ \\
\hline
\end{tabular}

${ }^{*} P<0.0001$ and ${ }^{\dagger} P<0.05$ by Student's $t$-test. NP, normal-protein; BW, body weight; LP, low-protein; NS, no statistical difference.

Published by Bioscientifica Ltd. 

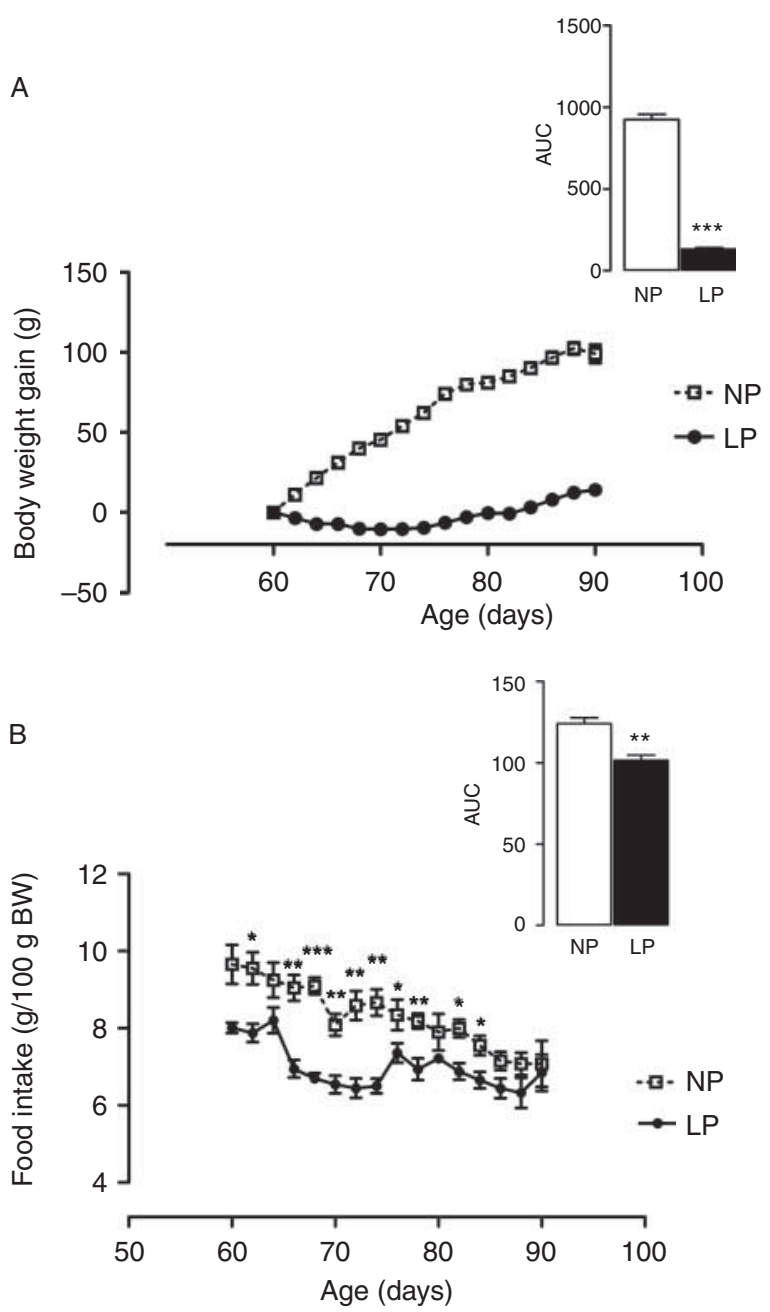

Figure 1

Body weight (BW) gain and food intake. Data are presented as mean \pm S.E.M. of 20-24 rats from four to five different litters for each group. Progression of BW (A) from 60 to 90 days of age; and food intake (B) from 60 to 90 days of age, (during the LP diet). The inset to the two figures, shows the area under the curve (AUC). $* * * P<0.0001, * * P<0.01$, and $* P<0.05$ by Student's $t$-test. NP, normal-protein; LP, low-protein.

periepididymal $(12.4 \%)$, and visceral $(14.6 \%)$ fat pads of the LP rats compared with the NP rats $(P<0.05, n=20-25)$. Finally, as shown in Table 1, the LP rats presented a $23 \%$ increase in ISI compared with the NP animals $(P<0.05$, $n=6)$. Severe growth retardation was observed during the LP diet treatment, resulting in a smaller BW in the LP rats compared with the NP rats, as shown in Fig. $1 \mathrm{~A}(P<0.0001$, $n=20-24)$. During the same period, the LP rats ate less than the NP rats, as shown in Fig. 1B. The AUC for food intake also decreased by $18 \%(P<0.01, n=4-5$ litters $)$.

After the protein restriction treatment had ended, BW growth increased significantly in the LP group compared with the NP group. The LP rats exhibited catch-up growth between 90 and 150 days, with higher AUC values compared with the NP animals $(P<0.0001, n=20-24$; Fig. 2A). When the food intake was evaluated during the same period, the LP rats ate $10 \%$ more than the NP rats $(P<0.05, n=4-5$ l; Fig. 2B).

\section{Plasma glycemia and insulinemia during the ivGTT}

Data from the ivGTT are shown in Fig. 3; a modest increase of $8 \%$ in the total glycemia of the LP rats was observed compared with the NP rats, as indicated by the AUC in Fig. 3A $(P<0.01, n=15-16)$. The insulin levels of the LP rats were $15 \%$ higher than those of the NP rats during the ivGTT, as shown by the AUC in Fig. 3B $(P<0.05, n=15-16)$.
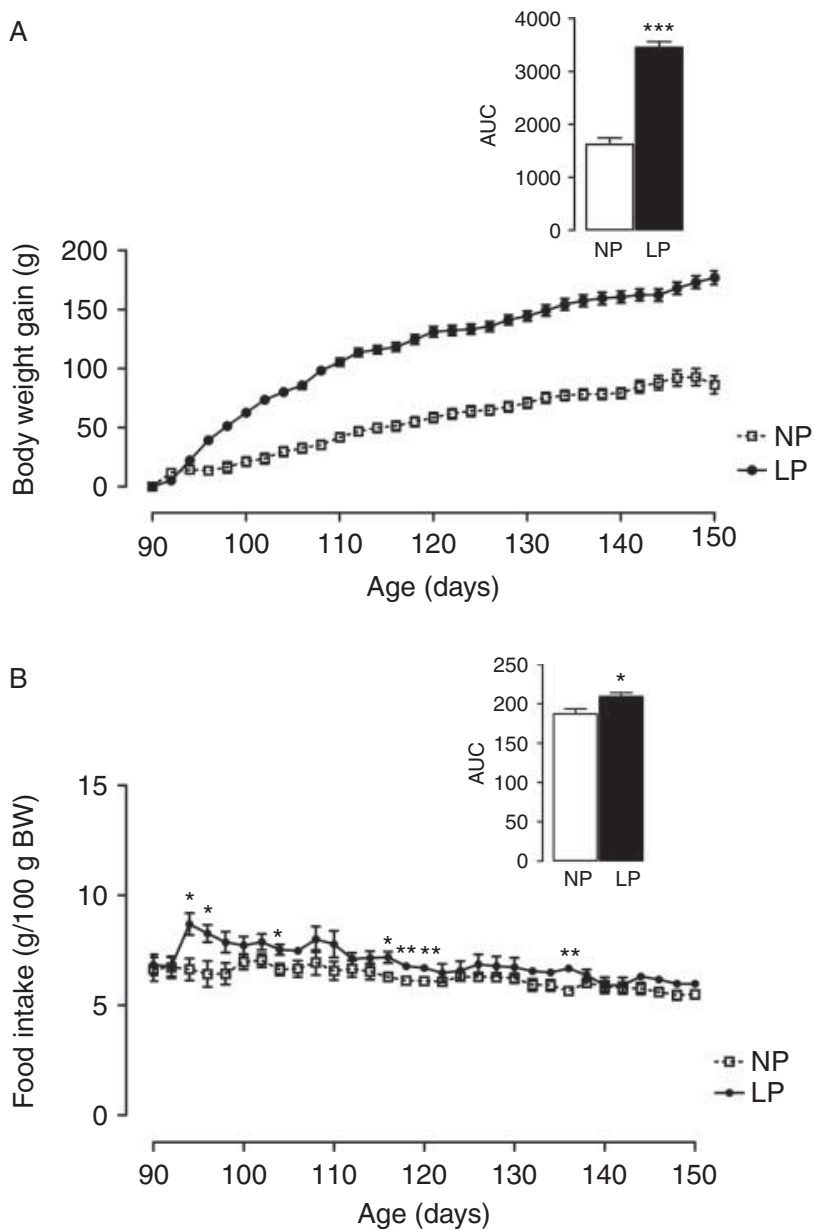

Figure 2

Body weight (BW) gain and food intake. Data are presented as mean \pm S.E.M. of 20-24 rats from four to five different litters for each group. Progression of BW (A) from 90 to 150 days of age; and food intake (B) from 90 to 150 days of age (after the LP diet was replaced by an NP one). The inset to the two figures, shows the area under the curve (AUC). $* * * P<0.0001, * * P<0.01$, and $* P<0.05$ by Student's $t$-test. $N P$, normal-protein; LP, low-protein. 
A
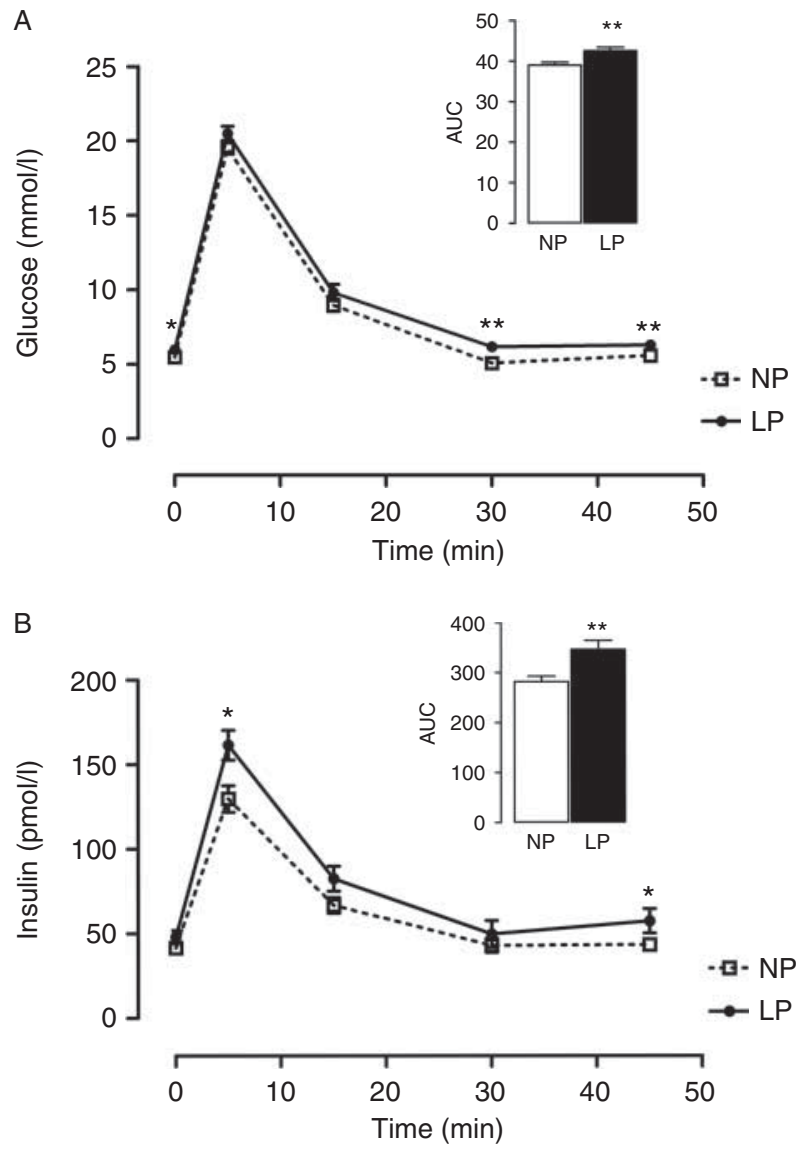

Figure 3

Plasma glycemia (A) and insulinemia (B) during the intravenous glucose tolerance test (ivGTT). Data are presented as mean \pm s.E.M. of 13-17 rats at least from four to five different litters. The inset for each figure shows the area under the curve (AUC). ${ }^{* *} P<0.01$ and $* P<0.05$ by Student's $t$-test. $N P$, normal-protein; LP, low-protein.

\section{Glucose-induced insulin secretion and muscarinic/ adrenergic regulation on this process in isolated pancreatic islets}

Isolated pancreatic islets from both experimental groups, when exposed to increasing glucose concentrations, increased insulin secretion in a dose-dependent manner, and the secretory response did not show any significant magnitude differences between the two groups (Fig. 4; $P=0.588, n=16$ ).

Figure 5 shows the effects of the mAChR agonist and antagonists on the insulinotropic effects of acetylcholine. Glucose $(8.3 \mathrm{mmol} / \mathrm{l})$ stimulated insulin secretion in the islets of both groups. In addition, the insulinotropic effect of acetylcholine on glucose-induced insulin secretion was increased by twofold in islets of both groups compared with their respective controls (Fig. 5A; $P<0.01, n=16$ ); however, no significant differences were observed between the LP and the NP islets groups ( $P=0.455, n=16)$. The use of a non-selective mAChR antagonist, atropine, inhibited the insulinotropic action of acetylcholine by 43 and $51 \%$ in isolated islets from the LP and NP rats respectively $(P<0.001$, $n=16$ ). A similar effect was observed with the use of the $\mathrm{mAChR} \mathrm{M}_{3}$ subtype-selective antagonist, 4-DAMP, but there were no significant differences between the LP and NP islets groups ( $P=0.073, n=16)$. On the other hand, islets incubated with methoctramine, a $\mathrm{mAChR} \mathrm{M}_{2}$ subtypeselective antagonist, exhibited an increased insulinotropic effect of acetylcholine of $\sim 20 \%$ in both the LP and the NP islet groups $(P<0.05, n=16)$, but without any significant differences in the magnitude (Fig. 5B; $P=0.6, n=16$ ).

As expected, $16.7 \mathrm{mmol} / \mathrm{l}$ glucose stimulated insulin secretion in the islets of both groups in a similar way (Fig. 6A); however, when isolated islets were incubated with epinephrine, a $40 \%$ inhibition of insulin secretion was observed in the islets of both groups (Fig. 6A; $P<0.0001, n=16$ ). The use of yohimbine, a selective $\alpha_{2}$-adrenoceptor antagonist, blocked the insulinostatic effect of epinephrine, causing potentiation of 250 and $155 \%$ for the glucose-induced insulin secretion in islets from the NP and LP rats respectively (Fig. 6B; $P<0.0001, n=16$ ). On the other hand, the use of a selective $\beta_{2}$-adrenoceptor antagonist, propranolol, provoked an inhibition of 34 and 33\% for the glucose-induced insulin secretion in the presence of epinephrine in islets from the NP and LP groups respectively $(P<0.05, n=16)$.

\section{Effect of an LP diet treatment on ANS activity}

Compared with the NP rats, the LP rats exhibited an increase of $21 \%$ in the superior vagus nerve activity $(P<0.05$, $n=17-23$; Fig. 7A and C), and the sympathetic nerve firing rate was decreased by $28 \%(P<0.01, n=17-23$; Fig. $7 \mathrm{~B}$ and C).

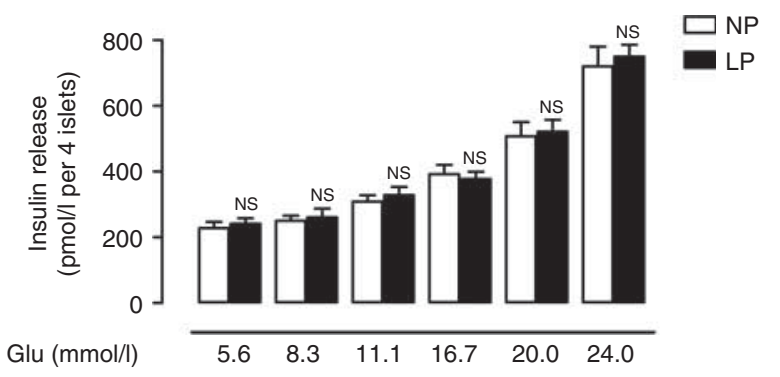

Figure 4

Insulinotropic effect of different glucose concentrations. Data are presented as mean \pm s.E.M. of insulin secreted by the pancreatic islets obtained from four to eight rats from at least four or five different litters. Statistical analyses between NP and LP groups for each different glucose concentrations were carried out by Student's $t$-test. NP, normal-protein; LP, low-protein; NS, no significant difference.
(C) 2014 Society for Endocrinology Printed in Great Britain 
A

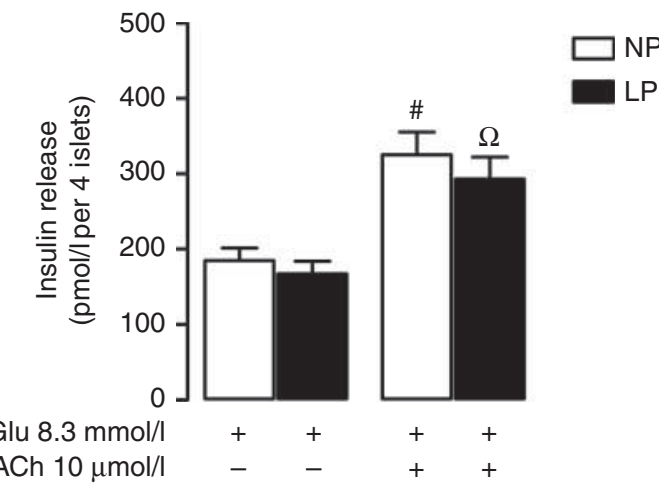

B
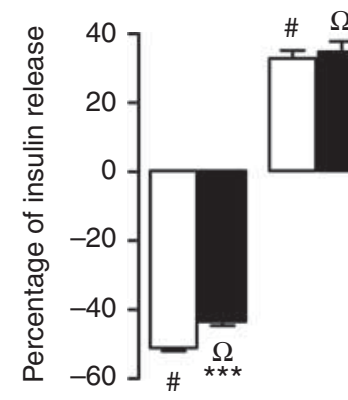

Atr $10 \mu \mathrm{mol} / \mathrm{l}$

MTT $1 \mu \mathrm{mol} / \mathrm{l}$

4-DAMP $100 \mu \mathrm{mol} / \mathrm{l}$

$++$

$\begin{array}{ll}- & - \\ + & +\end{array}$

$-$

$-$

\section{Figure 5}

Effect of muscarinic receptor agonist and antagonists on glucose-induced insulin secretion. Data represent mean \pm s.E.M. of insulin secreted by pancreatic islets from six rats from four to five different litters. (A) Insulin secretion stimulated by $8.3 \mathrm{mmol} / \mathrm{l} \mathrm{Glu}$ and potentiated by $10 \mu \mathrm{mol} / \mathrm{l} \mathrm{ACh}$. Symbols above the bars indicate significance levels: ${ }^{\#} P<0.001$ for the NP and ${ }^{\Omega} P<0.01$ for the LP group treated with $10 \mu \mathrm{mol} / \mathrm{l}$ ACh compared with those treated with $8.3 \mathrm{mmol} / \mathrm{l} \mathrm{Glu}$ by one-way ANOVA. (B) The zero value represents $100 \%$ glucose-induced insulin release potentiated by $10 \mu \mathrm{mol} / \mathrm{I}$ ACh in both the NP and LP groups. Bars above or below to the zero level represent the percentage increase or decrease provoked by the indicated concentrations of nonselective antagonist (Atr) and agonists selective to $\mathrm{M}_{2} \mathrm{mAChR}$ (MTT), and $\mathrm{M}_{3} \mathrm{mAChR}$ (4-DAMP) on glucose-induced insulin release potentiated by $10 \mu \mathrm{mol} / \mathrm{l}$ ACh in both NP and LP groups. Symbols above or below the bars indicate significance levels: $* * *<0.001$ between the NP and LP groups, ${ }^{\#} P<0.01$ for each indicated muscarinic antagonist compared with $10 \mu \mathrm{mol} / \mathrm{l}$ ACh treatment for the NP, or ${ }^{\Omega} P<0.01$ for the LP group by one-way ANOVA. NP, normal-protein; LP, low-protein; Glu, glucose; ACh, acetylcholine; Atr, atropine; MTT, methoctramine; 4-DAMP, 4-diphenylacetoxy- $N$-methylpiperidine methiodide.

\section{Discussion}

In addition to DOHaD concept, which links stressful stimulus early in life to metabolic changes later in life, we have shown for the first time, to our knowledge, that a LP diet treatment starting during early adulthood can promote changes in metabolism later in adulthood, as indicated by increased food intake, fat tissue accretion, glucose intolerance, and peripheral tissue insulin

resistance. Although these effects are not as robust as those found in adult rats that were protein-malnourished during maternal pregnancy and/or the lactation period (Roseboom et al. 2001), metabolism impairment is evident in adult rats that were protein-restricted at the beginning of adulthood.

In rats treated with a LP diet (8\% protein starting at 60 days old for 6 months), the total number of neurons in the hippocampus were reduced without changes in the hippocampal synapses even after 2 months of nutritional rehabilitation (Lukoyanov \& Andrade 2000). Our data indicate that protein restriction during the beginning of adulthood changes glucose and energy metabolism, which might persist in the later stage of life even when the LP diet intervention had been removed. Protein malnourishment during pregnancy causes evident obesity when the rodents reach adulthood (Anguita et al. 1993, Fernandez-Twinn \& Ozanne 2006, Howie et al. 2012); however, the current study does not provide strong enough evidence to indicate that a LP diet during young adulthood provokes obesity later in life. The current results indicate the induction of a slight increase in fat tissue, which is supported by a modest increase in insulin blood levels after a glucose bolus infusion. It has been shown that insulin and leptin are hormones associated with tissue adiposity. Increasing insulin levels indicate an increase in lipogenesis (Schwartz et al. 2000). Adolescent rats that received a LP diet from 30 to 60 days of age exhibited hyperinsulinemia, severe hyperleptinemia, insulin resistance, high-fat-tissue accretion, and disruption of $\beta$-cell function later in life (de Oliveira et al. 2012b). The end of adolescence occurs very close to protein deprivation period used in the current protocol, indicating that during early adulthood animals may have a propensity to undergo metabolic changes that can persist as a long-term consequence, similar to the perinatal and pubertal developmental stages. Although the present data indicate that protein restriction during early adulthood causes significant changes in metabolism, the magnitude of these events is minor compared with the metabolic disruptions observed when the nutritional insult occurs during the perinatal phase (Barbosa et al. 1999, Vickers et al. 2000). In addition, a LP maternal diet provokes metabolism dysfunction in the offspring of these rats when they reach adulthood that correlates with the severity of the protein deprivation (Barbosa et al. 1999). Therefore, with less severe protein restriction, such as the $8 \%$ protein diet or higher-protein diets, differences such as increased fat tissue storage and insulin resistance might not have been observable.

Published by Bioscientifica Ltd. 
A

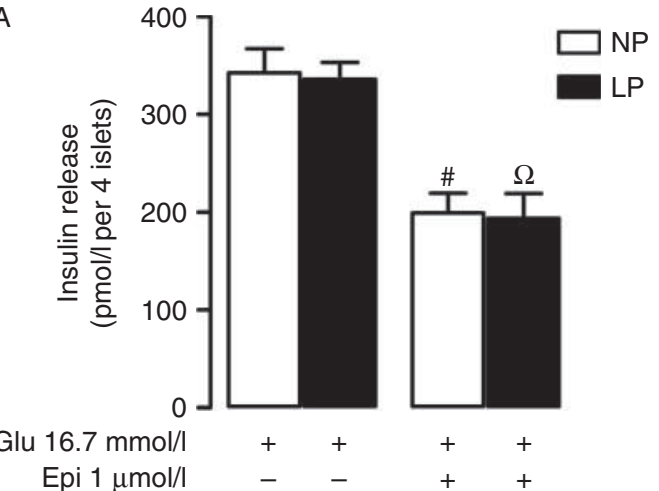

B

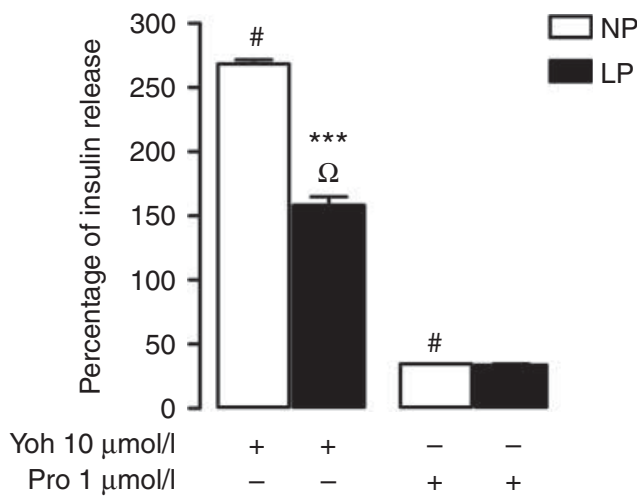

\section{Figure 6}

Effect of adrenoceptors agonist and antagonists on glucose-induced insulin secretion. Data represent mean \pm s.E.M. of insulin secreted by pancreatic islets from six rats from four or five different litters. (A) Insulin secretion stimulated by $16.7 \mathrm{mmol} / \mathrm{l} \mathrm{Glu}$ and blocked by $1 \mu \mathrm{mol} / \mathrm{l} \mathrm{Epi}$. Symbols above the bars indicate significance levels: ${ }^{\#} P<0.0001$ for the NP and ${ }^{\Omega} P<0.0001$ for the LP group treated with $1 \mu \mathrm{mol} / / \mathrm{I}$ Epi compared with the values for treatment with to $16.7 \mathrm{mmol} / \mathrm{l} \mathrm{Glu}$ by one-way ANOVA. (B) The zero value represents the insulin secretion stimulated by $16.7 \mathrm{mmol} / \mathrm{l} \mathrm{Glu}$ in the presence of $1 \mu \mathrm{mol} / \mathrm{I} \mathrm{Epi}$ for both NP and LP groups. Bars represent the percentage increase triggered by the indicated concentrations of selective $\alpha_{2}$-adrenoceptor (Yoh), and $\beta_{2}$-adrenoceptor (Pro) antagonists on insulin secretion stimulated by $(16.7 \mathrm{mmol} / \mathrm{l} \mathrm{Glu}$ in the presence of $1 \mu \mathrm{mol} / \mathrm{l} \mathrm{Epi})$ in both NP and LP groups. Symbols above the bars indicate significance levels: $* * * P<0.0001$ among NP and LP groups; ${ }^{*} P<0.05$ for the NP, and ${ }^{\Omega} P<0.0001$ for the LP islets treated with $10 \mu \mathrm{mol} / /$ Yoh or $10 \mu \mathrm{mol} / \mathrm{l}$ Pro in relation to $10 \mu \mathrm{mol} / \mathrm{l}$ Epi treatment by one-way ANOVA. NP, normal-protein; LP, lowprotein; Glu, glucose; Epi, epinephrine; Yoh, yohimbine; Pro, propanolol.

In the current study, unchanged BW gain associated with decreased food intake is evident in the LP rats from 60 to 90 days of age, implying that energy metabolism is drastically affected by the LP diet treatment. Proteincalorie deprivation has been reported to be a key factor involved in alterations in the energy-controlling hypothalamic neurons (Plagemann et al. 2000b, Attig et al. 2008, Delahaye et al. 2008). According to the thrifty phenotype hypothesis, protein-calorie deprivation programs the metabolism for survival, in this case starvation status, which may endure long-term; however, in the opposite situation in which the nutritional content is higher, disturbances may appear because of the metabolic programing imprinted previously (Vickers et al. 2000, Hales \& Barker 2001). Indeed, we observed that the LP rats presented high catch-up growth associated with high food intake immediately after replacement of the LP diet with the 2-month diet rehabilitation. Also, the unbalanced activity of the ANS was a remarkable finding of the current study. The high vagus tonus associated with low sympathetic activity may induce LP rats to be obesityprone. In agreement with the autonomic hypothesis (Inoue et al. 1991), recognized as a key factor involved in obesity onset and/or maintenance; our data might be important for highlighting that undernourishment, even in adulthood, could disturb autonomous functions controlling energy metabolism.

Metabolism homeostasis is highly dependent on the quantity and activity of insulin. Pancreatic $\beta$-cells, which are one of four cell types of pancreatic islets, produce, store, and release insulin into the blood stream. Therefore, $\beta$-cells play a pivotal role in the regulation of metabolism (Gautam et al. 2006, Chang-Chen et al. 2008). $\beta$-cells are very sensitive to insults during any phase of life, especially during early and late life, which can result in malfunctions with limited capacity for regeneration or neogenesis (Dumortier et al. 2007, Frantz et al. 2012, Supale et al. 2012). In contrast with other periods of LP intervention such as pregnancy, lactation, and adolescence (Hoet et al. 1992, Reusens \& Remacle 2006, de Oliveira et al. 2011, $2012 b$ ), a LP diet during early young adult life does not have a significant effect on the function of the pancreatic islets. Islets isolated from the LP rats exhibit the same glucose-induced insulin secretion magnitude as the NP rats, suggesting that pancreatic $\beta$-cells are resistant to LP diet insult early in adulthood, at least up to 150 days of age.

In spite of the known long-lasting disturbances in glucose-induced insulin secretion due to the nutritional injuries imprinted early in life (Ozanne et al. 2006, Zambrano et al. 2006, Fagundes et al. 2007), acute effects of food deprivation, such as weak insulin secretion of pancreatic islets, have been reported in adult rats after a 48-h fast (Carpinelli et al. 1986) or even as a result of protein or calorie restriction, which, interestingly, have induced hypoinsulinemia (Leon-Quinto et al. 1998) or hyperinsulinemia (He et al. 2012), respectively, immediately after the diet-restriction treatment. However, these metabolic changes have been observed immediately after the stressor effects, implying that even during later developmental

Published by Bioscientifica Ltd. 

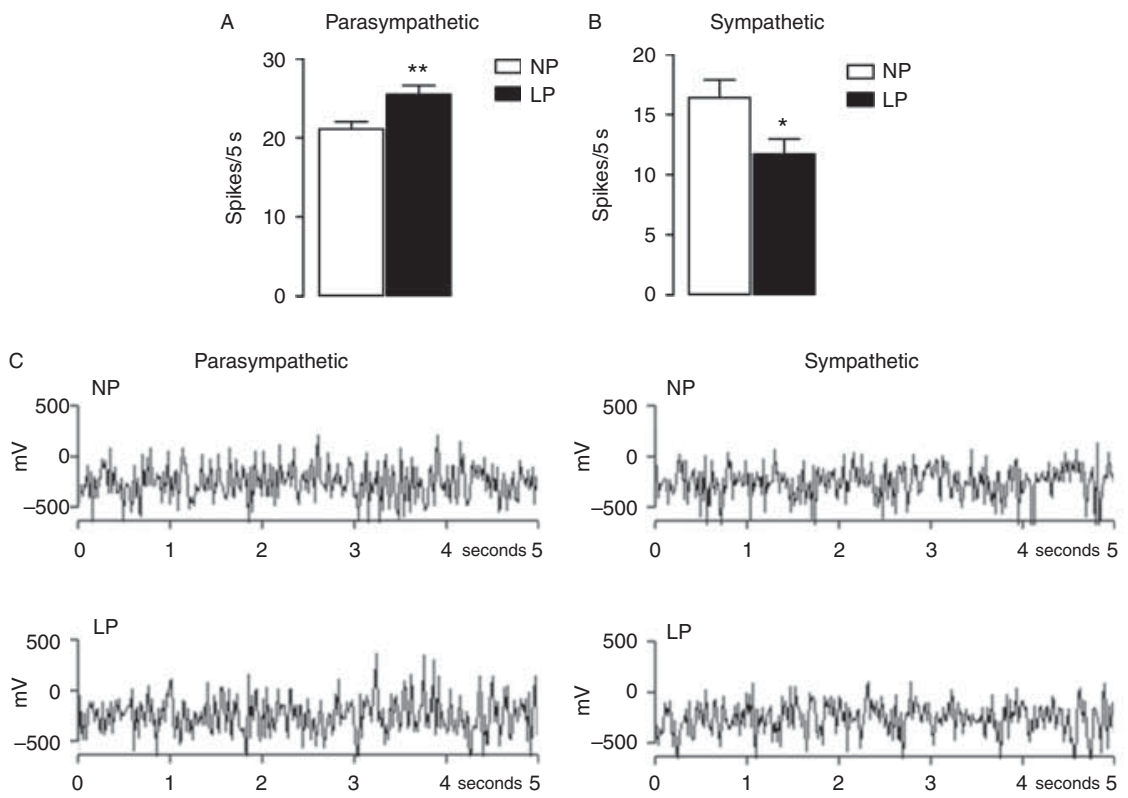

Figure 7

Sympathetic and parasympathetic electrical activity from the cervical superior nerves. Bars represent mean \pm S.E.M. of the firing rates of the vagus (A) and cervical sympathetic (B) nerves from 17-23 rats from five to seven

stages, physiological machinery adjustments are used to maintain the glucose-insulin homeostasis. In contrast, the stressor effects of protein-deprivation were spread over a long time, as the current work used a short period of stress followed by nutritional rehabilitation. Although the ability of pancreatic islets to secrete insulin in response to either glucose or muscarinic agents was not affected, metabolic impairments commonly diagnosed in obese and/or prediabetic individuals are present, indicating that phenotype changes similar to the those induced early in life by intrauterine undernutrition were imprinted in the LP rats even during a later stage of life (with low plasticity in organ/tissue development). It has been previously reported that humans who experienced the Dutch hunger winter between 1944 and 1945 over a short time during childhood, adolescence and/or young adulthood exhibited a strong tendency for the development of type 2 diabetes later in life (van Abeelen et al. 2012), which supports the results of this study.

Those results and the data presented in the current study indicate that pancreatic $\beta$-cells have a great capacity to resist nutritional stress insults or have a potential functional recovery rate in the later developmental stages of life, even under the unbalanced action of the ANS which exhibits a pivotal role in controlling insulin secretion.

http://joe.endocrinology-journals.org DOI: 10.1530/JOE-13-0473
(C) 2014 Society for Endocrinology Printed in Great Britain different litters. Representative records of nerve tonus are shown in the lower panel. ${ }^{*} P<0.01$ and ${ }^{*} P<0.05$ by Student's $t$-test. NP, normalprotein; LP, low-protein.

Changes in the epinephrine secretory response of $\beta$-cells were observed in which glucose-induced insulin secretion was potentiated by an $\alpha_{2}$-adrenoceptor antagonist with a greater magnitude in the isolated islets from the LP rats. These results were associated with high electrical firing of the vagus nerve and low sympathetic tonus, indicating the influence of an ANS imbalance on the number and function of adrenergic receptors in the pancreatic $\beta$-cells. A close relationship has been observed between pancreatic islet malfunction and impairment of the ANS in adult rats and mice that were metabolically programmed early in life (Balbo et al. 2007, Grassiolli et al. 2007, Gravena et al. 2007, de Oliveira et al. 2011); Scomparin et al. (2009) however, muscarinic and adrenergic receptor of pancreatic $\beta$-cells did not show substantial functional differences in the current study.

In conclusion, protein restriction performed during early adulthood induces weak hallmarks of metabolic malfunctions in rats later in life; however, pancreatic $\beta$-cell function is not affected, indicating that during young adulthood, the central architecture and peripheral control of metabolism are already close to completion of their development. The data presented here provide a better understanding of the concept of $\mathrm{DOHaD}$ by highlighting the importance of the early phases of life in programming lifelong metabolism patterns, even though

Published by Bioscientifica Ltd. 
some impairment could be imprinted by stressful nutritional insults after the main critical developmental periods had passed.

\section{Declaration of interest}

The authors declare that there is no conflict of interest that could be perceived as prejudicing the impartiality of the research reported.

\section{Funding}

This work was supported by the Brazilian Federal Foundation, Conselho Nacional de Desenvolvimento Científico e Tecnológico (CNPq) and Coordenação de Aperfeiçoamento de Pessoal de Nível Superior (CAPES), and the Paraná Science Foundation (Fundação Araucária).

\section{Author contribution statement}

$A M$ and $P C F M$ designed the study and revised the manuscript; A M, J C O, TA S R, LP T, K V P, R A M, G E, C C S F, A R A, A B T, and A P conducted the research; A M, J C O, LF B, C G, and LAN analyzed the data; A M and P C F M wrote the manuscript; and P C F M acted as the principal investigator, provided support, and reviewed the data and manuscript.

\section{Reference}

van Abeelen AF, Elias SG, Bossuyt PM, Grobbee DE, van der Schouw YT, Roseboom TJ \& Uiterwaal CS 2012 Famine exposure in the young and the risk of type 2 diabetes in adulthood. Diabetes 61 2255-2260. (doi:10.2337/db11-1559)

Alamy M \& Bengelloun WA 2012 Malnutrition and brain development: an analysis of the effects of inadequate diet during different stages of life in rat. Neuroscience and Biobehavioral Reviews 36 1463-1480. (doi:10.1016/j.neubiorev.2012.03.009)

Anguita RM, Sigulem DM \& Sawaya AL 1993 Intrauterine food restriction is associated with obesity in young rats. Journal of Nutrition $\mathbf{1 2 3}$ $1421-1428$

Attig L, Djiane J, Gertler A, Rampin O, Larcher T, Boukthir S, Anton PM, Madec JY, Gourdou I \& Abdennebi-Najar L 2008 Study of hypothalamic leptin receptor expression in low-birth-weight piglets and effects of leptin supplementation on neonatal growth and development. American Journal of Physiology. Endocrinology and Metabolism 295 E1117-E1125. (doi:10.1152/ajpendo.90542.2008)

Balbo SL, Grassiolli S, Ribeiro RA, Bonfleur ML, Gravena C, Brito Mdo N, Andreazzi AE, Mathias PC \& Torrezan R 2007 Fat storage is partially dependent on vagal activity and insulin secretion of hypothalamic obese rat. Endocrine 31 142-148. (doi:10.1007/s12020-007-0021-z)

Barbosa FB, Medina AR, Balbo SL \& de Freitas Mathias PC 1999 Low protein diets administered to lactating rats affect in a time-dependent manner the development of young. Research Communications in Molecular Pathology and Pharmacology 106 63-76.

Barbosa FB, Capito K, Kofod H \& Thams P 2002 Pancreatic islet insulin secretion and metabolism in adult rats malnourished during neonatal life. British Journal of Nutrition 87 147-155. (doi:10.1079/BJN2001489)

Barker DJ 2004 The developmental origins of chronic adult disease. Acta Paediatrica Scandinavica 93 26-33. (doi:10.1111/j.1651-2227. 2004.tb00236.x)

Barker DJ \& Bagby SP 2005 Developmental antecedents of cardiovascular disease: a historical perspective. Journal of the American Society of Nephrology 16 2537-2544. (doi:10.1681/ASN.2005020160)

http://joe.endocrinology-journals.org DOI: $10.1530 /$ JOE-13-0473
(C) 2014 Society for Endocrinology Printed in Great Britain
Bouret SG, Gorski JN, Patterson CM, Chen S, Levin BE \& Simerly RB 2008 Hypothalamic neural projections are permanently disrupted in diet-induced obese rats. Cell Metabolism 7 179-185. (doi:10.1016/ j.cmet.2007.12.001)

Carpinelli AR, Mathias PC, Leclercq-Meyer V \& Malaisse WJ 1986 Fastinginduced dissociation of cationic and secretory events in pancreatic islets. Cell Biochemistry and Function 4 123-130. (doi:10.1002/cbf.290040208)

Chang-Chen KJ, Mullur R \& Bernal-Mizrachi E 2008 -cell failure as a complication of diabetes. Reviews in Endocrine \& Metabolic Disorders 9 329-343. (doi:10.1007/s11154-008-9101-5)

Cripps RL \& Ozanne SE 2006 The relationship between poor growth rate and increased risk of type 2 diabetes, insulin resistance and obesity. Expert Review of Pharmacoeconomics \& Outcomes Research 6 79-86. (doi:10.1586/14737167.6.1.79)

Delahaye F, Breton C, Risold PY, Enache M, Dutriez-Casteloot I, Laborie C, Lesage J \& Vieau D 2008 Maternal perinatal undernutrition drastically reduces postnatal leptin surge and affects the development of arcuate nucleus proopiomelanocortin neurons in neonatal male rat pups. Endocrinology 149 470-475. (doi:10.1210/en.2007-1263)

Dumortier O, Blondeau B, Duvillie B, Reusens B, Breant B \& Remacle C 2007 Different mechanisms operating during different critical time-windows reduce rat fetal $\beta$ cell mass due to a maternal lowprotein or low-energy diet. Diabetologia 50 2495-2503. (doi:10.1007/ s00125-007-0811-0)

Fagundes AT, Moura EG, Passos MC, Oliveira E, Toste FP, Bonomo IT, Trevenzoli IH, Garcia RM \& Lisboa PC 2007 Maternal low-protein diet during lactation programmes body composition and glucose homeostasis in the adult rat offspring. British Journal of Nutrition 98 922-928. (doi:10.1017/S0007114507750924)

Fernandez-Twinn DS \& Ozanne SE 2006 Mechanisms by which poor early growth programs type- 2 diabetes, obesity and the metabolic syndrome. Physiology \& Behavior 88 234-243. (doi:10.1016/j.physbeh. 2006.05.039)

Frantz ED, Peixoto-Silva N \& Pinheiro-Mulder A 2012 Endocrine pancreas development: effects of metabolic and intergenerational programming caused by a protein-restricted diet. Pancreas 41 1-9. (doi:10.1097/MPA. Ob013e3182236320)

Gautam D, Han SJ, Hamdan FF, Jeon J, Li B, Li JH, Cui Y, Mears D, Lu H, Deng $\mathrm{C}$ et al. 2006 A critical role for $\beta$ cell M3 muscarinic acetylcholine receptors in regulating insulin release and blood glucose homeostasis in vivo. Cell Metabolism 3 449-461. (doi:10.1016/j.cmet. 2006.04.009)

Grassiolli S, Gravena C \& de Freitas Mathias PC 2007 Muscarinic M2 receptor is active on pancreatic islets from hypothalamic obese rat. European Journal of Pharmacology 556 223-228. (doi:10.1016/j.ejphar. 2006.11.022)

Gravena C, Mathias PC \& Ashcroft SJ 2002 Acute effects of fatty acids on insulin secretion from rat and human islets of Langerhans. Journal of Endocrinology 173 73-80. (doi:10.1677/joe.0.1730073)

Gravena C, Andreazzi AE, Mecabo FT, Grassiolli S, Scantamburlo VM \& Mathias PC 2007 Protein restriction during lactation alters the autonomic nervous system control on glucose-induced insulin secretion in adult rats. Nutritional Neuroscience 10 79-87. (doi:10.1080/10284150701308693)

Greenwood PL \& Bell AW 2003 Consequences of intra-uterine growth retardation for postnatal growth, metabolism and pathophysiology. Reproduction Supplement 61 195-206.

Hales CN \& Barker DJ 2001 The thrifty phenotype hypothesis. British Medical Bulletin 60 5-20. (doi:10.1093/bmb/60.1.5)

He XY, Zhao XL, Gu Q, Shen JP, Hu Y \& Hu RM 2012 Calorie restriction from a young age preserves the functions of pancreatic $\beta$ cells in aging rats. Tohoku Journal of Experimental Medicine 227 245-252. (doi:10.1620/ tjem.227.245)

Hoet JJ, Dahri S, Snoeck A, Reusens-Billen B \& Remacle C 1992 Importance of diets and their effect on fetal development: function and structure of the endocrine pancreas following protein deficiency during 
intrauterine life. Bulletin et Mémoires de l'Académie Royale de Médecine de Belgique 147 174-181 (discussion 181-183).

Howie GJ, Sloboda DM \& Vickers MH 2012 Maternal undernutrition during critical windows of development results in differential and sex-specific effects on postnatal adiposity and related metabolic profiles in adult rat offspring. British Journal of Nutrition 108 298-307. (doi:1REF7=10.1079/ BJN2001489)

Inoue S, Nagase H, Satoh S, Saito M, Egawa M, Tanaka K \& Takamura Y 1991 Role of the efferent and afferent vagus nerve in the development of ventromedial hypothalamic (VMH) obesity. Brain Research Bulletin 27 511-515. (doi:10.1016/0361-9230(91)90151-9)

Leon-Quinto T, Magnan C \& Portha B 1998 Altered activity of the autonomous nervous system as a determinant of the impaired $\beta$-cell secretory response after protein-energy restriction in the rat. Endocrinology 139 3382-3389. (doi:10.1210/endo.139.8.6149)

Lesage J, Sebaai N, Leonhardt M, Dutriez-Casteloot I, Breton C, Deloof S \& Vieau D 2006 Perinatal maternal undernutrition programs the offspring hypothalamo-pituitary-adrenal (HPA) axis. Stress 9 183-198. (doi:10.1080/10253890601056192)

Lopes Da Costa C, Sampaio De Freitas M \& Sanchez Moura A 2004 Insulin secretion and GLUT-2 expression in undernourished neonate rats. Journal of Nutritional Biochemistry 15 236-241. (doi:10.1016/j.jnutbio. 2003.12.004)

Lukoyanov NV \& Andrade JP 2000 Behavioral effects of protein deprivation and rehabilitation in adult rats: relevance to morphological alterations in the hippocampal formation. Behavioral Brain Research 112 85-97. (doi:10.1016/S0166-4328(00)00164-9)

Matsuda M \& DeFronzo RA 1999 Insulin sensitivity indices obtained from oral glucose tolerance testing: comparison with the euglycemic insulin clamp. Diabetes Care 22 1462-1470. (doi:10.2337/diacare.22.9.1462)

Ng SF, Lin RC, Laybutt DR, Barres R, Owens JA \& Morris MJ 2010 Chronic high-fat diet in fathers programs $\beta$-cell dysfunction in female rat offspring. Nature 467 963-966. (doi:10.1038/nature09491)

de Oliveira JC, Scomparin DX, Andreazzi AE, Branco RC, Martins AG, Gravena C, Grassiolli S, Rinaldi W, Barbosa FB \& Mathias PC 2011 Metabolic imprinting by maternal protein malnourishment impairs vagal activity in adult rats. Journal of Neuroendocrinology 23 148-157. (doi:10.1111/j.1365-2826.2010.02095.x)

de Oliveira JC, Grassiolli S, Gravena C \& de Mathias PC 2012a Early postnatal low-protein nutrition, metabolic programming and the autonomic nervous system in adult life. Nutrition \& Metabolism 980. (doi:10.1186/1743-7075-9-80)

de Oliveira JC, Lisboa PC, de Moura EG, Barella LF, Miranda RA, Malta A, Franco CC, Ribeiro TA, Torrezan R, Gravena C et al. $2012 b$ Poor pubertal protein nutrition disturbs glucose-induced insulin secretion process in pancreatic islets and programs rats in adulthood to increase fat accumulation. Journal of Endocrinology 216 195-206. (doi:10.1530/ JOE-12-0408)
Ozanne SE, Jensen CB, Tingey KJ, Martin-Gronert MS, Grunnet L, Brons C, Storgaard H \& Vaag AA 2006 Decreased protein levels of key insulin signalling molecules in adipose tissue from young men with a low birthweight: potential link to increased risk of diabetes? Diabetologia 49 2993-2999. (doi:10.1007/s00125-006-0466-2)

Plagemann A, Harder T, Rake A, Melchior K, Rohde W \& Dorner G $2000 a$ Hypothalamic nuclei are malformed in weanling offspring of low protein malnourished rat dams. Journal of Nutrition 130 2582-2589.

Plagemann A, Waas T, Harder T, Rittel F, Ziska T \& Rohde W $2000 b$ Hypothalamic neuropeptide $Y$ levels in weaning offspring of lowprotein malnourished mother rats. Neuropeptides 34 1-6. (doi:10.1054/ npep.1999.0778)

Reusens B \& Remacle C 2006 Programming of the endocrine pancreas by the early nutritional environment. International Journal of Biochemistry \& Cell Biology 38 913-922. (doi:10.1016/j.biocel.2005.10.012)

Roseboom TJ, van der Meulen JH, Ravelli AC, Osmond C, Barker DJ \& Bleker OP 2001 Effects of prenatal exposure to the Dutch famine on adult disease in later life: an overview. Molecular and Cellular Endocrinology 185 93-98. (doi:10.1016/S0303-7207(01)00721-3)

Schwartz MW, Woods SC, Porte D Jr, Seeley RJ \& Baskin DG 2000 Central nervous system control of food intake. Nature $\mathbf{4 0 4} 661-671$. (doi:10.1038/35007534)

Scomparin DX, Gomes RM, Grassiolli S, Rinaldi W, Martins AG, de Oliveira JC, Gravena C \& de Freitas Mathias PC 2009 Autonomic activity and glycemic homeostasis are maintained by precocious and low intensity training exercises in MSG-programmed obese mice. Endocrine 36 510-517. (doi:10.1007/s12020-009-9263-2)

Scott AM, Atwater I \& Rojas E 1981 A method for the simultaneous measurement of insulin release and B cell membrane potential in single mouse islets of Langerhans. Diabetologia 21 470-475. (doi:10.1007/ BF00257788)

Supale S, Li N, Brun T \& Maechler P 2012 Mitochondrial dysfunction in pancreatic $\beta$ cells. Trends in Endocrinology and Metabolism 23 477-487. (doi:10.1016/j.tem.2012.06.002)

Trinder P 1969 Determination of blood glucose using an oxidaseperoxidase system with a non-carcinogenic chromogen. Journal of Clinical Pathology 22 158-161. (doi:10.1136/jcp.22.2.158)

Vickers MH, Breier BH, Cutfield WS, Hofman PL \& Gluckman PD 2000 Fetal origins of hyperphagia, obesity, and hypertension and postnatal amplification by hypercaloric nutrition. American Journal of Physiology. Endocrinology and Metabolism 279 E83-E87.

Zambrano E, Bautista CJ, Deas M, Martinez-Samayoa PM, GonzalezZamorano M, Ledesma H, Morales J, Larrea F \& Nathanielsz PW 2006 A low maternal protein diet during pregnancy and lactation has sexand window of exposure-specific effects on offspring growth and food intake, glucose metabolism and serum leptin in the rat. Journal of Physiology 571 221-230. (doi:10.1113/jphysiol.2005.100313)

Received in final form 25 February 2014

Accepted 4 March 2014

Accepted Preprint published online 5 March 2014 http://joe.endocrinology-journals.org DOI: $10.1530 / \mathrm{JOE}-13-0473$
() 2014 Society for Endocrinology Printed in Great Britain
Published by Bioscientifica Ltd 